\section{LA MEJOR MUJER DE LA COLONIA: IMÁGENES FEMENINAS DE LA VILLA IMPERIAL DE POTOSÍ}

\author{
SUSANA SANTOS \\ Universidad de Buenos Aires \\ su_santos@yahoo.com
}

\title{
RESUMEN
}

Bartolomé Arzanz y Vela, autor de Historia de la Villa Imperial de Potosí, iniciada en 1736 y escrita durante treinta y cinco años, definió a la rica Villa Imperial como «la mujer» en la «pareja originaria y soberana del mundo"; su hombre es el Cerro Rico. El edificio emblemático de la Villa, la Real Casa de Moneda, adquiere en las páginas de Brocha Gorda (Julio Lucas Jaimes) la caracterización de la casa natal donde la figura central es la madre (la Villa). En la reciente literatura de Argentina, país receptor de migrantes bolivianos, la dama potosina reaparece en las novelas Bolivia Construcciones (2006) y Grandeza Boliviana (2010) de Bruno Morales.

Palabras clave: Mujeres, América Colonial, Potosí, Migrantes y Migraciones, Bolivia, Literatura Boliviana, Arzanz, Brocha Gorda, Bruno Morales.

\section{ABSTRACT}

Bartolomé Arzanz y Vela, author of History of the Imperial City of Potosi, which he began in 1736 and wrote for thirty-five years, defined the prosperous Imperial City as «the woman» in the «original partnership, sovereign in the world», her «man» being the Mountain where the rich silver mines were. The city landmark, the Royal Mint, in the pages of Brocha Gorda (Julio Lucas Jaimes) is characterized as the family home where a woman, the mother (the «Villa»), plays center stage. In recent literature in Argentina, where most of the Bolivian migrants go, the lady of Potosi comes to life in the novels Bolivia Construcciones (2006) and Grandeza Boliviana (2010) by Bruno Morales.

Keywords: Women, Colonial America, Potosí, Migrantes and Migrations, Bolivia, Bolivian Literature, Arzanz, Brocha Gorda, Bruno Morales.

[...] la sordidez esotérica de la Siempre Ínclita, Noble y Rica Villa Imperial de Potosí de Don Carlos V. En la oscuridad de la noche caminaban los fantasmas de los clérigos de las treinta y tres iglesias sombrías. Y qué decir de las casonas enrejadas de crujientes umbrales, de los hombres armados de mosquetes y espadas, de las mujeres bien vestidas y de carne satisfecha, de los borrachos estruendosos que cantaban en los caramancheles de olores malignos [...] En medio del silencio las quejas, los gritos plañideros, los gemidos prolongados, las voces dolientes de los negros que desde los subterráneos de la Casa Real de la Moneda clamaban el perdón de Dios

(Néstor Taboada Terán, 1977, p. 217)

Hacia 1546, un desordenado agrupamiento de viviendas a los pies del Cerro Rico de Potosí dio origen a la villa más mentada de
Susana Santos

Profesora de Problemas de Literatura Latinoamericana (Cátedra Viñas, Facultad de Filosofía y Letras, Universidad de Buenos Aires). Entre sus publicaciones, destacan $\mathrm{Ho}$ menaje a Pablo de Rokha (1996), El primer centenario en México (editora, 1995) y Arte, revolución y decadencia. Revistas vanguardistas en América Latina. 1924-1931 (coeditora, 2009). Ha participado en volúmenes colectivos con ensayos críticos como «Historias de la historia. Simpatías y diferencias del proyecto Capítulo en la historiografía argentina (1917-1979)», «Santa Rosa Luxemburgo: contemporaneizar el Perú en el programa de Amauta»; «Ite misa est; Casa de cartón de Martín Adán», «Canción de oro en primavera: la imagen del martifierrismo en sus claves latinoamericana» $\mathrm{y}$ «El lugar de la alegoría: las relaciones cambiantes del espacio en la novelística de los Andes, desde Yawar Fiesta hasta Bolivia Construcciones».
La mejor mujer de la colonia: imágenes femeninas de la Villa Imperial de Potosí

SUSANA SANTOS 


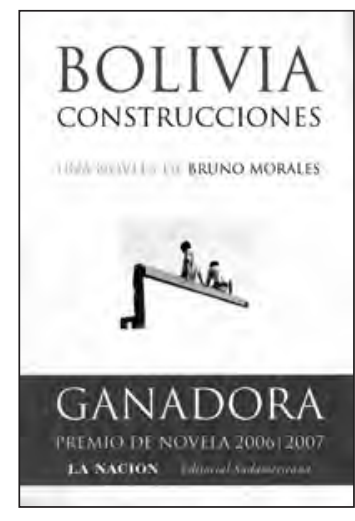

Bruno Morales, Bolivia Construcciones. Portada.
La mejor mujer de la colonia: imágenes femeninas de la Villa Imperial de Potosí

SUSANA SANTOS los siglos coloniales, emplazada a cuatro mil metros sobre el nivel del mar. Su primer historiador fue el criollo potosino Nicolás de Martínez Arzans y Vela o Bartolomé Martínez y Vela, también Bartolomé Arzanz Sánchez y Vela: varios nombres para una sola persona, que suman intriga novelesca sobre la identidad de este grandioso cronista. Su Historia de la Villa Imperial de Potosí, iniciada en 1736 y escrita durante treinta y cinco años, quedó inconclusa a la muerte de su autor, y permaneció inédita dos siglos (salvo copias truncas y adelantos de su autor en unos Anales) hasta que fue editada en tres tomos, en 1965, por la Brown University Press, con estudio preliminar de Lewis Hanke y Gurnaz Mendoza.

El Cerro era conocido por los habitantes anteriores de la región como Sumaj Orkbo (Cerro Hermoso), pero también como Photojsi (de «potoy», en aymara, ruido), por el ruido que hacía cuando lo quisieron horadar, y paradójicamente para las imágenes coloniales no como un hombre sino como una mujer, Coya (reina). Cuando los vegetales que lo cubrían y le prodigaban variadas tonalidades de gris, marrón, amarillo y verde, fueron desapareciendo mientras los mitayos morían, el cerro quedó rojo y fue llamado Wulka Chollo (Cerro de sangre). Los españoles, voluntariosamente ajenos a esta sucesión de nombres, llamaron a la ciudad y a la montaña de manera unívoca: Potosí. El indio Diego Haullpa descubrió una veta de plata en este huaco sagrado y -a pesar de la prohibición secular- lo comunicó a los conquistadores. Las batallas para impedir el saqueo del metal sagrado, encabezadas por Chaqui Catari, no pudieron impedir el avance expoliador europeo. «El furioso aire a todas horas procuraba echarlos de aquel sitio", informa el autor de la Historia de la Villa Imperial (Arzans y Vela, 2003, p. 145). Dieciocho meses más tarde, había al pie del cerro 2.500 casas con catorce mil habitantes. Los 160.000 habitantes de 1562 hacían de la villa la doncella virginal la que tenía más hijos en América.

Historia de la Villa Imperial de Potosí define el Cerro y la Villa como la primigenia pareja soberana del orbe, opuestos como el macho y la hembra en dos páginas enfrentadas, ponderada con una serie innúmera de adjetivos que alcanzan su clímax descriptivo cuando ambos -el Cerro y la Villa- cobran, finalmente, corpus después de haber sido anima, la corporeidad precisa de un hombre y una mujer.

\section{I}

El cronista es claro en el reconocimiento histórico y consuetudinario de atributos sexuales y genéricos, pero también etarios:

quien corren los pinceles y pintan en figuras y hierogliferos de un venerable viejo con cana y lengua barba, sentado en el centro de su bien formada máquina, adornado de preciosos vestidos de plata, ceñidas sus sienes de imperial corona rodeada de triunfador laurel, cetro en la diestra mano, en la siniestra una barra de plata ofreciéndola a los pies de las reales armas que a su lado tiene, debajo de los cofres de riquezas, piñas de su precioso metal, barras y monedas, esparciéndolo a sus plantas. Pintan a la Villa, en figura de hermosísima y grave doncella, sentada a la falda del Cerro, con riquísimos vestidos, adornando sus sienes imperial diadema, cetro en la diestra mano puesta sobre el mundo y con la siniestra tomando barras del rico Cerro unas en pos de otras para ofrecérselas (Arzans y Vela, 2003, p. 135).

En la trama de esta historia par pero impar, el dolor y la muerte de los indios es vivida en simultáneo con la caballeresca pendencia y avaricia de criollos y peninsulares. Más de 4.000 indios registra este autor, con sus vidas y sus muertes, utilizados para la construcción de las lagunas que servían a las dieciocho represas mandadas a construir por el virrey Toledo, a fin de proveer de fuerza hidráulica necesaria para la extracción del metal que dotaba de fama a la hermosa doncella, cuasi virginal, de la Imperial Villa. Durante el gobierno de este Virrey (1569-1580) la ciudad se reorganizó: a diferencia de las del resto del Virreynato del Perú y de otras en las inmensas tierras sudamericanas -también en esto fue impar-, nació sin acta y cuadrícula que expresaran el sueño del orden. En su origen hay, en cambio, el abigarrado desorden de un caserío con calles serpenteantes y desiguales. Por cédula de Carlos V (1546) se concedió el título de fundador a Juan de Villarroel. Con el título, llegaron sus emblemas: el escudo de armas con el cerro rico (donde no faltaba la incitación a la envidia fálica): «soy el rico Potosí / del mundo soy el tesoro / soy el rey de los montes y envidia soy de los reyes» (Arzans y Vela, 2003, p. 160), dos columnas con dos cintas donde está escrito Plus Ultra y figurada la corona imperial. Luego, anteriormente al planeamiento de la ciudad que impuso el virrey Toledo, un nuevo escudo 
(1566): dos leones, dos castillos y un águila entre las columnas de Hércules.

El Cerro, masculino y dador, se convirtió en un mito universal que sustituyó a la búsqueda de El Dorado, y alcanzó rápidamente la universalidad: Don Quijote le promete a Sancho que si lo libra del encantamiento de Dulcinea «fuera poco para pagarte las minas de Potosí» (Cervantes, 1876, p. 472). En 1650, León Pinelo afirmó que con la plata extraída del cerro hubiera sido posible un puente de 14 varas de ancho entre Potosí y Madrid (Francovich, 1980, p. 79). En los años de la Revolución de 1952, el escritor y político boliviano Augusto Céspedes precisará: «Un puente de plata, sí. Pero paralelo podría haber otro puente tan grande como el anterior con los cadáveres de los indios mitayos que murieron en sus minas» (Céspedes, 1974, p. 84). Por el contrario, para potosinos y altoperuanos, el cerro conservó siempre un carácter religioso: un ídolo enigmático, generoso y cruel al mismo tiempo.

Respecto a su dama, para ella será el argentino metal; para ella, de España vendrán los tejidos; de Francia los sombreros; de Flandes, los espejos; de Alemania, las espadas; de Arabia, los perfumes; de China, las sedas; de Venecia los cristales; del Cuzco, el azúcar; del Tucumán, los cueros; de Panamá, las perlas...

La Villa -opulenta mujer de la plata, la más celebrada de los dominios coloniales y de ultramar- tentaba (Eva, al principio y al fin) con la aventura del oro como posibilidad teórica y práctica, como ensueño y empresa, que resultó derecho exclusivo de los peninsulares y solo por acaso de contados criollos. Los nativos, por el contrario, en relación con las minas, nunca pudieron pensar en términos monetaristas de oro o plata, como señal de prosperidad, sino que entregaban sus vidas al dolor, a la miseria y a la muerte. La Villa Imperial, también figurada mujer en esto, despliega su territorio -su cuerpo- para que otros cuerpos la transiten: hormigueante presencia de la gente en sus calles y plazuelas, de las actividades de las cocineras y ganapanes, los mesones y posadas completas de pasajeros, las actividades del mercado y abasto en el emplazamiento que luego será la Plaza del Regocijo. Los torneos y juegos de sortijas, las fiestas religiosas y paganas. Se la llamó la «Babilonia del Perú» pero esto sólo acendra el profundo vínculo de fondo místico, sentimental, idealista y a la vez hedonista que los hombres de ese tiempo establecieron con la única mujer «a quienes todos desean por refugio, solicitan por provecho, anhelan por gozarla y la gozan por descanso» (Arzans y Vela, 2003, p. 113).

Ese clímax, para nada exento de la dinámica violencia de esa sociedad potosina, fue evocado en numerosas crónicas cuyo catálogo, para evitar una enumeración fatigosa, no puede excluir las del argentino Vicente G. Quesada, del peruano Ricardo Palma, de los bolivianos Julio Lucas Jaimes (Brocha Gorda), Modesto Omiste y José Manuel Aponte, ni tampoco las del chileno Benjamín Vicuña. El primerísimo entre todos, y más próximo de ese clímax que registra mes a mes, fue desde luego Arzans.

En honor a la ciudad, floreció un arte indígena, que superó con creces al importado de la Península. Melchor Pérez de Holguín, llamado el Greco de América, expresó en su pintura religiosa el talento de un arte mestizo, en el cuadro de la Virgen María con los brazos abiertos que da de mamar con un pecho al niño y con el otro a San José. La Villa Imperial fue reedificada u ordenada -como se indicó- en sentido opuesto a las que entonces eran sus dos rivales: la Ciudad de los Reyes, Lima, construida cerca del Pacífico para negar al Cuzco, el ombligo del mundo; y la ciudad de México, que «el extremeño cruel», Hernán Cortés -en gesto político inequívoco- fundó sobre las ruinas humeantes de Tenochtitlan. En la Villa Imperial durante el siglo XVIII -y precisamente cuando la riqueza que parecía inagotable del cerro se angostaba-, improvisada y después planificada para el lucro colonial, se levantarán los costosos templos de increíbles portadas como la Iglesia de San Lorenzo, sobre el cual el minucioso registro de nuestro cronista deja constancia que en los años 1728 y 1744 estaban tallando los indígenas. Las sirenas mueven con su música los astros del cielo; la luna, el sol y las estrellas, que están juntos recuerdan a las deidades de Quesintuu y Umantuu que habitan en los lagos, antiguos mitos del Collasuyo; pero también remiten a la teoría, entre pitagórica y platónica, de que los astros del cielo son movidos por el canto de las sirenas. Arte mestizo para «la muy ce-
La mejor mujer de la colonia: imágenes femeninas de la Villa Imperial de Potosí

SUSANA SANTOS 


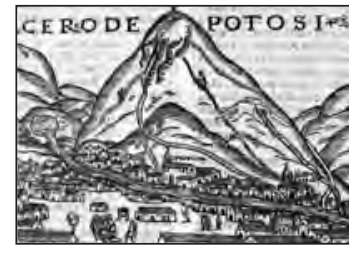

Cerro de Potosí.
1

El peruano Ricardo Palma en sus Tradiciones es acaso el escritor que más contribuyó a la configuración de la «tapada» limeña como la versión femenina de la ciudad. La Malinche, o Doña Marina, india intérprete de Hernán Cortés, es vista como la mujer violada ("chingada»). Véase al respecto Octavio Paz (1988)

La mejor mujer de la colonia: imágenes femeninas de la Villa Imperial de Potosí

SUSANA SANTOS lebrada, siempre ínclita, magnánima, noble y rica villa de Potosí, orbe abreviada; honor y gloria de las Américas; emperatriz de las villas y lugares de este Nuevo Mundo; reina de su poderosa provincia; princesa de las indianas poblaciones» (Arzans y Vela, 2003, p. 113). La real señora imperial se distingue de la «tapada» ${ }^{1}$ limeña que las crónicas y tradiciones configuran como la versión femenina de Lima, y de la «chingada» mexicana que, en sus versiones más atenuadas, se presenta como cifra y símbolo del mestizaje.

\section{II}

«Es peligroso saltar a la orilla opuesta; pero nada se pierde en probarlo a no ser la vida».

El enigmático y a la vez expreso acertijo sobre reales y posibles riesgos de vida podía leerse en un letrero que desde inmemoriales pero memorables tiempos estaba emplazado en un pico cercano a la Real Casa de Moneda potosina. Brocha Gorda, seudónimo de Julio Lucas Jaimes, cronista potosino que abrevó en Arzans y Vela, nació y vivió su infancia y juventud en la urbe colonial casi intacta en su estancamiento republicano, fue tradicionista de la Villa. La única edición de su libro $\mathrm{La}$ Villa Imperial de Potosí data de 1905 y fue impresa en Buenos Aires. «De la Casa Real de Moneda y asuntos concomitantes», donde la historia de esta emblemática construcción, cifra de la historia de la misma ciudad, adquiere las caracterizaciones de la casa natal que remite como figura central y femenina de la madre, la villa aún opulenta

es una ciudadela populosa aquella casa que los potosinos amamos como parte de nuestro propio ser unido a los recuerdos más tiernos de la infancia, a las tradiciones más fantásticas de la juventud, a los prestigios más estimados de la historia. A ese edificio están vinculados los nombres de familia patricia, muchas de largo abolengo y de blasones ilustres [....] del no recordar cayendo quizás en falta involuntaria, porque si hay algo patriarcal y sincero y perdurable, aun dados los políticos contrarios bandos existentes, es el afecto fraternal que aún hoy conservamos a la recíproca los vástagos de aquellas familias potosinas que duermen el sueño de la eternidad [....] en la opulenta villa, que aún goza de no eclipsada fama en el universo mundo (Brocha Gorda, 1964, p. 18).
Brocha Gorda nos informa que la Real Casa de Moneda fue denominada, alguna vez, en un contexto revolucionario de contextos muy precisos, con el nombre de otro símbolo femenino, la Bastilla, en la intención de hacerla representar el poder arbitrario que se encastilla entre sus muros: cuando había revueltas o peligro de ellas, se encerraban en la Moneda, los cautivos, los tesoros, los jefes de mando, los funcionarios. El edificio, comenzado en 1753 y concluido en 1773 , persistió -después del esplendor vibrante y fugaz del ciclo de una plata que todavía no era boliviana sino de la «república de los españoles», no de la «de los indios»- sin el epíteto Real que «la democracia le arrebató, celosa como novia en luna de miel, excediéndose en el amor al gobierno del pueblo por el pueblo, que [...] hoy lo paga todo como antes y aún peor, mucho más que antes de ser soberano» (Brocha Gorda, 1964, p. 6).

Potosí nunca recuperó un lugar central -económico y cultural- en tiempos de la otra nueva República nacida y bautizada por las guerras y victorias bolivarianas. Su decadencia invocada por el genial Arzans y Vela en su dolida demanda: «Dime, famosa Villa de Potosí ¿qué se hizo de tu antigua grandeza?» (Arzans y Vela, 2003, p. 190)- significó un ascenso del poder hacia el norte paceño: el estaño y la goma.

Ante su imparable decadencia, la mujer más afamada, más rica y poderosa de esos años, pero más en los anteriores, dejó expresa su ultima voluntad: «Sepan todos como Yo: / La villa de Potosí / otorgo mi testamento / por temer un frenesí// Las cuatro partes del mundo/ mi féretro cargarán/ y todas ellas que han muerto/ sus tributarias serán». El poema «Testamento de Potosí», anónimo que se publicó en esa ciudad, en el año 1800, enumera a todos aquellos que asistirán al velorio: Buenos Aires, Chile, La Rioja, Tucumán, Paraguay, Jujuy, Oruro, Cuzco, Lima, Chuquisaca, La Paz, Santa Cruz, Cochabamba, Tarija, La Costa, Atacama. Una cuarteta octosilábica dedicada a cada uno define el nuevo juego de poderes de la región.

El primero que nombra es Buenos Aires: «Mi hijo, el Niño Buenos Aires, /a quien virreynato di, / irá en el medio cantando / «aprended flores de mí» (Anónimo, 1964, p. 23). Luego, la muy «Noble, Fidelísima Imperial Villa de Potosí» (así el último verso, atribuyéndose la autoría) prosigue: «El entie- 
rro está dispuesto / seguiré mi testamento. // Primeramente declaro / que hija legítima soy / del Católico Monarca / que me dio el ser con quien estoy // Doña América es mi madre, / India, Noble, Rica, Franca, / alta, linda, algo trigueña / pero me parió muy blanca [....] Declaro que por mostrarme / ser Madre de hijos ajenos / mucho he quitado a los míos [....] Con todo, por remorderme la conciencia de esta acción, pido perdón, pues no hay como / hacer la restitución» (Anónimo, 1964, p. 25).

\section{III}

«No hay como hacer la restitución» obligará a los potosinos o al menos a su gran mayoría a saltar a la orilla opuesta; «nada se pierde en probarlo a no ser la vida». Supone el audaz y a veces imposible impulso por traspasar fronteras clasistas, nacionales, étnicas, lingüísticas. El fracaso, al menos inmediato, de la Revolución de 1952, marcado por el golpe del general Hugo Banzer Suárez en 1971, pondrá de manifiesto hasta qué punto la vida de los habitantes del altiplano, donde la primero doncella y después señora de la Villa de Potosí ocupaba un lugar egregio, será una vida de emigraciones. Y esta experiencia será, precisamente en la orilla opuesta del país privado del mar, transitada en la misteriosa Buenos Aires construida de espaldas al río inmóvil, que ya no admite ser tratada como «hijo» por esa mujer del poema anónimo.

Ciudad capital del país cuyo nombre-Argentina, nombre que Martín del Barco Centenera en su poema otorga a la tierra del Río de la Plata- evoca por coincidencia de sonidos al metal no menos argentino y recuerda que su fundación fue en pos de la búsqueda del camino de la plata prodigiosa del Alto Perú, según lo testifica el nombre del río que pareció mar a la porfía de Juan de Solís (Chiaramonte, 2008). Buenos Aires fue puerto de mercancías y esclavos durante doscientos años, con miras a las ciudades de Charcas, La Paz y, principalmente, a la Villa Imperial de Potosí -de quien recibía importante subsidio-, que sí contaba con fastuosas catedrales, iglesias y aun palacios. La republicana Generación porteña de 1837 y sus descendientes intelectuales dieron un marco político liberal a la inmigración que idealmente debía acercar e incluso hacer proliferar modelos culturales y mano de obra de más allá del Atlántico, en todas las zonas de un país cuyo mayor mal, según proclamó
Sarmiento en el Facundo, era su extensión. A pesar de los miedos que suscitó y a pesar, acaso por encima de todo, de no provenir de los centros esperados (sus puntos de partida, contra las ensoñaciones solitarias, y arias, de Juan Bautista Alberdi en las Bases, fueron las periferias europeas que

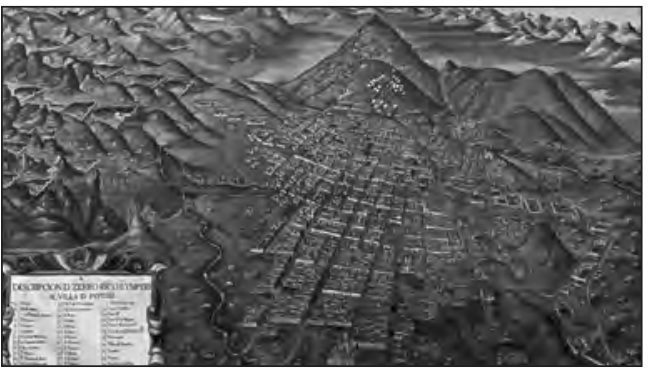
G. M. Berris, Descripción de Potosí. 1758. Museo Colonial del Charcas. habían desconocido los beneficios de la Revolución Francesa), la llamada «migración histórica» vivió en la Argentina una experiencia de integración. Resultó favorecido el masivo contingente de españoles e italianos, que se distinguió menos que otras etnias y nacionalidades del solar de la raza trazado por el santafesino Manuel Gálvez.

El de esa migración, que tuvo su clímax en el centenario de 1910, es el camino, tan estudiado por historiadores (aun de la literatura), que va, de manera no siempre gratificante, no siempre decepcionante, oscilando desde la metáfora de la Babel porteña hasta la del «crisol de razas». No faltó el orgullo al hablar de la capital argentina como de una ciudad europea, sin indios ni negros residuales.

Buenos Aires, fue, sin duda, la ciudad cuyo crecimiento llamó más la atención de los europeos hasta convertirse en un pequeño mito. El francés H. D. Sisson, escribía en 1909 que Buenos Aires era «una ciudad nueva que había crecido con la rapidez de un hongo sobre la pampa desierta» y equivocándose en los datos, resumía así su interés por la capital argentina. «Esta ciudad de Buenos Aires, es un fenómeno del que es necesario hablar. El hecho del desarrollo de lo que era en 1875 una ciudad de setenta mil almas y que en 1906 ocupa una extensión más grande que París, edificada en sus dos tercios y poblada por un millón doscientos cincuenta mil habitantes, es más maravilloso que la aparición de la ciudad más grande de Estados Unidos» (Romero, 1976, p. 251).

Las migraciones de países limítrofes y andinos conocieron un clímax velado y asordinado en la década de 1990, cuando el peso estuvo cambiariamente igualado al dólar, lo que permitió el envío de remesas desde la Argentina a los países de origen: una nueva plata podía volver a Potosí, la dama recibía un tributo externo y tardío. Buenos Aires y su conurbano se convirtieron así en primera ciu-
La mejor mujer de la colonia: imágenes femeninas de la Villa Imperial de Potosí

SUSANA SANTOS 


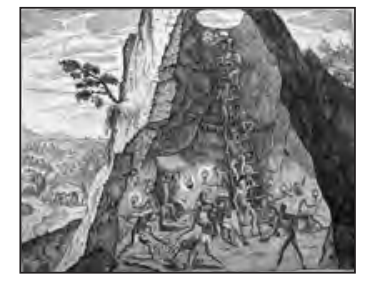

Indígenas extrayendo plata del Cerro Rico.

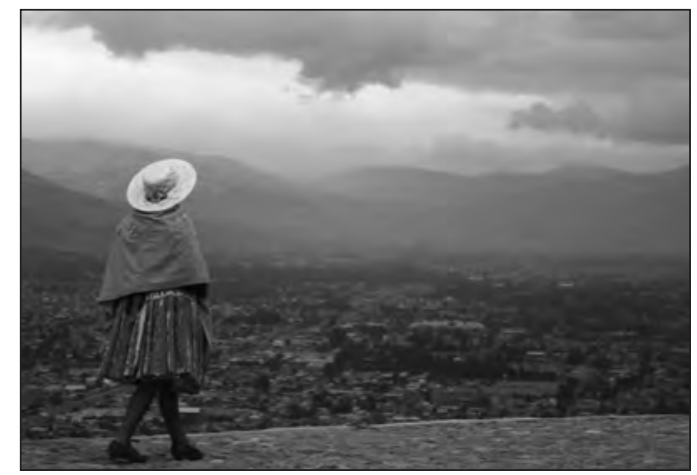

Mujer boliviana.

dad boliviana, con una demografía que desafía a la Paz, a El Alto y a Santa Cruz de la Sierra.

En la literatura reciente publicada en Argentina, la dama reaparece en Buenos Aires en las novelas Bolivia Construcciones (2006) y Grandeza Boliviana (2010), novelas del autor pseudónimo boliviano-argentino Bruno Morales. En Bolivia Construcciones, un innominado narrador potosino viaja de la Villa de Arzans de Orsúa y Vela (y del también pseudónimo «Brocha Gorda») hasta la villa del Bajo Flores, como también ocurre en Grandeza Boliviana.

La presencia de la migración boliviana en Argentina en tiempos recientes había sido tratada por la literatura antropológica, sociológica, histórica y cultural como también por el cine. Una de las novedades que propone Bolivia Construcciones y Grandeza Boliviana -en páginas compuestas por fantasías y alusiones literarias, pero no menos impregnadas de realidad- es la inesperada inclusión de un sector de la ciudad que excede lo que hasta el momento se consideraba típico o representativo de la novelística urbana: su narrador y protagonistas son migrantes de Bolivia.

Ambos libros tuvieron uno de sus orígenes en la percepción y sensibilidad de Bruno Morales de una urgente necesidad por ofrecer forma literaria a la experiencia de una comunidad en Buenos Aires -que otrora se llamó la Atenas y también la Sodoma del Plata-, que promueve transformaciones, y se ve transformada por ellas, pero también por otras que ni promovió ni aun anticipó. Las respuestas de estas novelas a preguntas que no siempre formulan, ni tienen por qué formular, y que columbran niveles poéticos, escénicos y políticos en las innegables mutaciones, no se elaboraron en soledad: el autor de estas no- velas, en varias de las entrevistas concedidas, hizo un relato a veces pormenorizado acerca de caminatas que duraron una década, y de vivencias compartidas en los lugares porteños con los migrantes de la Villa Imperial, y no sólo con ellos, que la novela ficcionaliza, en su curva desde la mejor mujer de la colonia, la argentina Potosí, hasta la Reina del Plata argentina.

\section{IV. «Es como volver a la Villa Imperial»}

-En esa tienda encontrarás lo que quieras- me hizo notar Quispe. Y en efecto, como las demás ofrecía verduras, papas, especias, pero también todo tipo de objetos en miniatura, casas, edificios, autos de colores flúo, bolsitas de alimentos disecados, sillones, títulos universitarios, valijas, novias, novios, bolívares, dólares y lingotes de oro.

-Ah, es como volver a la gran ciudad imperial. Acompáñame muchacho y no te pierdas

(Morales, 2006, p. 135).

Antes de que las novelas de Bruno Morales existieran, los migrantes bolivianos estaban irreductiblemente presentes. A mediados de la década de 1980, comenzaron a verse -o a hacerse ver- con mayor asiduidad en Buenos Aires y otros centros urbanos del país para mostrar los conflictos de sus ciudades de origen. Como también el trastorno de la ciudad que los recibía, haciéndoles notar que no los había convocado, que debían agradecer su sola presencia en una tierra rica-«sentí que este país me hacía un gran favor al dejarme entrar» (Morales, 2006, p. 10)»- y que se encaminaba a una crisis urbana que la acercaba más al resto de Latinoamérica que a una Europa ya lejana incluso como modelo.

El narrador innominado de Bolivia Construcciones, novela de la migración boliviana, pero donde no faltan peruanos, paraguayos y aun coreanos, arriba desde la Villa Imperial de Potosí a la Ciudad del Plata, que fue también llamada Reina del Plata, vive en la villa 1-11142. En este caso, poco hay de «imperial». Se trata de un asentamiento de emergencia, «de calles que trazaron los azares del hambre/ la súbita marea de los desposeídos / y de los desocupados forzosos; los ilusos/del patético éxodo provincias lejanas. / [....] Barrio de un Buenos Aires ignorado en la guía del turismo» (González Tuñón, 1963, p. 92).

El envés de la orgullosa ciudad de Buenos Aires es que disuelve todo abolengo, toda 
realeza: sólo por la pantalla de un televisor se pueden conocer reinas:

En la tele pasaban un documental sobre la belleza de las reinas de belleza argentinas: la del pejerrey, la del tomate, la de la pera, la de Mar del Plata, la del Hombre Petrolero. Con los viajes se conocen, recorren este país juntas. Se llaman entre ellas, «Damasco», «Vendimia», «Petróleo» (Morales, 2006, p. 27).

La presentación de la Villa 1-11-14 en estas novelas, sin vergüenza ni distanciamiento, o sin otros distanciamientos que los muy deliberados de una cultura literaria cuya ausencia puede deplorarse en algunos de los lectores de Bolivia Construcciones, permite trazar un puente que une la imperial casa de la mejor mujer de los siglos coloniales, la magnánima dadora de la plata, al implacable oxímoron de la ciudad del Plata en el Bajo Flores porteño. La longitud de este imaginario puente es de dos siglos de historia, a partir del nacimiento de las nuevas repúblicas americanas.

Cuando el narrador de la novela, un muchacho potosino, ingresa a la casa que ocuparán, observa lo que le muestra su virgilio en el laberinto villero, que responde al nombre quechua de Quispe: «Con un gesto mostraba la casa, de arriba abajo, y curvando el brazo, una ampliación, detrás del pasillo más angosto que hubiera visto nunca en mi vida» (Morales, 2006, p. 13). Para más adelante añadir:

Esa misma noche, sí aprecié la ampliación que me había señalado el Quispe. Era el baño, que estaba separado de la casa. La expedición que uno hacía era la justa penalidad por las ventajas derivadas de tenerlo lejos. Por unos caños salía no solamente un olor fétido, sino multitud de animales: arañas, unos gusanos gordos, cucarachas robustas y actuadas, de esas que embisten y atacan, y unos insectos que no he vuelto a ver, que tenían la peculiaridad de tener la panza llena de aire y de tronar al ser aplastados.

Pero la ventaja de ese bestiario era que lo veía uno al ir al baño y ahí lo dejaba y no volvía a acordarse de él hasta el próximo viaje (Morales, 2006, p. 16).

La transcripción corresponde al entero capítulo 4 de esta novela. El pasillo y su recorrido dan cuenta de la vida que llevan $-\mathrm{y}$ no solo ellos- los migrantes. La descripción que se dirige a la fantasía imitativa del lector, a su recuerdo o a la novedad que representen a esta calidad de ambientes, arroja la impresión intensa de desconsoladora pobreza, desgaste y ranciedad, pero al mismo tiempo de una fantasía surrealista, como de imagen de El Bosco.

Que este baño sea el espacio de la dramática pelea entre Sylvia y Mariano, ya en el capítulo 72 de los 84 que completan la novela, ilumina la captación de un acontecimiento presentado como corriente en ese medio pero que adquiere en la ficción tonalidad trágica; los personajes capaces de pasiones extremas se alejan de toda tipificación donde un fundamentalismo cultural, que puede hacerse más o menos consciente, los habría encasillado.

El momento -que es uno de los clímax de Bolivia Construcciones- señala también la (ficticia) iniciación sexual del narrador soñada por él mismo con modelos ajenos: la mejor mujer argéntea de la colonia reencontrada en las orillas argentinas y no menos colonizadas del Plata. Culminaciones de un modo de vida de los que se han atrevido «a saltar a la otra orilla», tienen como un escenario favorito por su densidad metafórica ese pasillo que no es sólo un lugar más de un barrio miserable, sino uno de sus no lugares, su continuación que pone a prueba la experiencia en esta otra ciudad de Plata, junto al río inmóvil.

La Villa Imperial del Potosí también tenía sus sinuosos y secretos laberintos, bóvedas secretas en las minas, cárceles oscuras. Y los lujos y esparcimientos - «son mozas, vino y naipes / el mundo, demonio y carne» (Brocha Gorda, 1964, p. 49)- que le permitían ser la mujer más admirada y poderosa de la época colonial: la Villa Imperial de Potosí. Pero esto no impidió que la exclusión de los mitayos, los pueblos originarios, fuera radicalmente feroz: en tres centurias, el Cerro Rico cobró ocho millones de indios ${ }^{3}$. Esos anómalos índices están ausentes en la ciudad del Plata pero sí se señala que esta mujer a espaldas del río, es también un espacio monstruoso condensado en el laberinto villero. El pasillo duplica el riesgo que implica el pasaje: «el saltar a la otra orilla», a más de un migrante le ha costado la vida. Las peripecias serán múltiples, en esta novela de seudónimo autor que es también novela de iniciación y recapitulación. Así concluye: «mis memorias serían como las de los que se han casado siete veces; los ratos buenos se han perdido en la noche de los tiempos, y solo queda el recuerdo de un millón de pleitos» (Morales, 2006, p. 203). El narrador anónimo de la novela pseudónima, está en consonancia con las palabras de la gran Villa, en su poema Testamento de Potosí, de

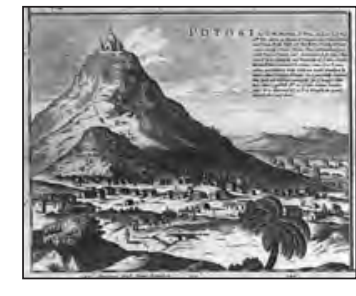

Potosí.

3

Veáse «Fiebre del oro, fiebre de la plata» en Las venas abiertas de América Latina (Galeano, 1971, pp. 17-88).
La mejor mujer de la colonia: imágenes femeninas de la Villa Imperial de Potosí

SUSANA SANTOS 


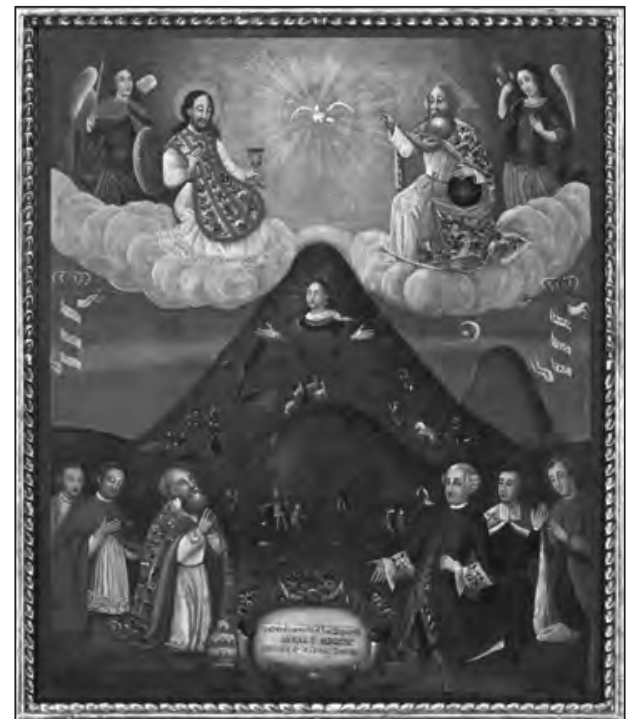

Anónimo. Virgen del Cerro. 1720. Museo de Arte de La Paz. anónimo autor: «Aquí yace un Potosí / tan otro de lo que fue / que hasta los ciegos le dicen: /quien te vido y quien te ve// [.... La Villa tan renombrada aquí su fama remata. / ¡Mucho para ser Nada / y nada para ser Plata //» (Anónimo, 1964, p. 27).

\section{Bibliografía}

Anónimo (1964), «Testamento de Potosí», en Bedregal, Yolanda (ed.), Poesía de Bolivia: De la época precolombina al modernismo, Buenos Aires, Eudeba, pp. 22-28.

Arzans y Vela, Nicolás de (2003 [1735]), Historia de la Villa Imperial de Potosí, Brown University de Providence, Rhode Island. Edición de Mariano Baptista Gumucio

Benencia, Roberto (2008), «Migrantes bolivianos en la periferia de ciudades argentinas: procesos y mecanismos tendientes a la conformación de territorios productivos y mercados de trabajo». Las migraciones en América Latina: Políticas, culturas y estrategias. Susana Novick (comp.), Buenos Aires, Clacso.

Brocha Gorda (Julio Lucas Jaimes) (1964), La Villa Imperial de Potosí, Buenos Aires, Eudeba.

Caggiano, Sergio (2008), «Racismo, fundamentalismo cultural y restricción de la ciudadanía: formas de regulación social frente a inmigrantes en Argentina». Las migraciones en América Latina. Políticas, culturas y estrategias. Susana Novick (comp.), Buenos Aires, Clacso.

Cervantes Saavedra, Miguel de (1876), El ingenioso Hidalgo Don Quijote de La Mancha, Madrid, Saturnino Calleja Fernández.
Céspedes, Augusto (1974), El Metal del Diablo, Buenos Aires, Eudeba.

Chiramonte, José Carlos (2008), «Del Río de la Plata a la Argentina», en José Carlos Chiaramonte, Carlos Marichal y Aimer Granados (compiladores), Crear la nación: Los nombres de los países de América Latina, Buenos Aires, Sudamericana, pp. 69-111.

Francovich, Guillermo (1980), Los mitos profundos de Bolivia. La Paz, Los amigos del Libro.

Galeano, Eduardo (1971), Las venas abiertas de América Latina, México, SXXI

González Tuñón, Raúl (1963), «Villa Miseria», en Buenos Aires, mi ciudad, Buenos Aires, Eudeba.

Guzmán, Augusto (1998), Historia de Bolivia. La Paz, Los amigos del Libro.

Mongin, Olivier (2006). La condición urbana. La ciudad a la hora de la mundalización, Buenos Aires, Paidós.

Morales, Bruno (2006), Bolivia Construcciones, Buenos Aires, Sudamericana (hay edición paceña de 2008, en Yerba Mala Editores).

Morales, Bruno (2010), Grandeza Boliviana, Buenos Aires, Eterna Cadencia.

Paz, Octavio (1988), El laberinto de la soledad, México, FCE.

Romero, José Luis (1976), Latinoamérica: Las ciudades y las ideas, Buenos Aires, Siglo XXI.

Shultz, Jim y Melissa Crane Draper (2008), Desafiando la globalización: Historia de la experiencia boliviana. La Paz, Plural.

Taboada Terán, Néstor (1977), Manchay Puytu: El amor que quiso ocultar Dios, Buenos Aires, Sudamericana.

Villavicencio, Susana y otros (2003), Los contornos de la ciudadanía. Nacionales y extranjeros en la Argentina, Buenos Aires, Eudeba.
La mejor mujer de la colonia: imágenes femeninas de la Villa Imperial de Potosí 